\title{
TITLE:
}

\section{INVERTEBRATE FAUNA OF THE INTERTIDAL ZONE OF THE TOKARA ISLANDS -VIII.MOLLUSCAN SHELLS-}

$\operatorname{AUTHOR}(S):$

Oyama, Katura; Yamamoto, Torao; Tokioka, Takasi

\section{CITATION:}

Oyama, Katura ...[et al]. INVERTEBRATE FAUNA OF THE INTERTIDAL ZONE OF THE TOKARA ISLANDS -VIII.MOLLUSCAN SHELLS-. PUBLICATIONS OF THE SETO MARINE BIOLOGICAL LABORATORY 1954, 4(1): 1-15

ISSUE DATE:

1954-11-20

URL:

http://hdl.handle.net/2433/174506

RIGHT: 


\title{
INVERTEB̈RATE FAUNA OF TḦE INTERTIDAL ZONE OF THE TOKARA ISLANDS \\ VIII. MOLLUSCAN SHELLS ${ }^{122)}$
}

\author{
KaTURA ÔYAMA, TORAO YAMAMOTO and TAKASI TOKIOKA
}

Molluscan shells of the following list were identified by the first two authors. The specimens, about 500 in all, were collected by the last author and composed of shells of living animals and empty shells stranded along the beach or picked up from the tips by the dwellings of the inhabitants of the islands. Names of molluscs found in the memorandums by the last author on the fauna of the Islands were also included in the list and marked by the abbreviation "mem." instead of the specimen number.

There still remain 115 specimens which could not be identified by the present authors and were submitted for further examination to Dr. T. KURODA and Mr. T. HABE, to whom we wish to express here our hearty thanks for their kindness in identifying some of the specimens listed below.

List of THE SPECIES IDENTIFIED

\section{GASTROPODA}

Fissurellidae 1. Emarginula variegata A. AdaMS

2. Scutus emarginatus (PHILIPPI)

3. Clypidina (Montfortula) pulchra (A. AdAms) 4. Diodora mus (REEVE)

\section{Takarazima}

TK. No. 435

436

437

444

Patellidae

5. Patella (Penepatella) optima PILsBry

441 $442^{*}$

6. Cellana toreuma (REEVE)

7. Cellana eucosmia (PILSBRY) ヘッコタザ
Nakanøsima

Scientific Survey of the Tokara Islands, Report No. 10.

2) Contributions from the Seto Marine Biological Laboratory, No. 234.

* Also found in Suwanosezima (mem.).

Publ. Seto Mar. Biol. Lab., IV (1), 1954. (Article 1) 
8. Cellana nigrisquamata (REEVE)

Lottiidae

9. Patelloida sp.

Trochidae

10. Alcyna ocellata A. ADAMS

11. Monodonta neritoides (PHILIPPI)

12. Clanculus stigmatarius A. AdAms

13. Trochus maculatus LINNÉ

14. ?Tectus (Pyramidea) maximus (PHILIPPI)

Turbinidae

15. Liotina peroni (KIENER)

16. Liotina (Dentarene) cycloma (Tomlin)

17. Collonista granulosa (PEASE)

18. Turbo (Olearia) marmoratus LINNÉ

19. Turbo (Marmarostoma) setosus GMELIN

20. Turbo (Marmarostoma) argyrostomus LINNÉ

Neritidae

21. Nerita (undata) striata BURROW

22. Nerita (Ritena) helicinoides laevilabris PILSBRY

23. Nerita (Ritena) plicata LINNÉ

24. Nerita (Ritena) costata GMELIN

25. Nerita (Ritena) reticulata KARSTEN

26. Nerita (Theliostyla) albicilla LINNÉ

27. Nerita (Amphinerita) polita LINNÉ

28. Nerita (Amphinerita) insculpta RÉcLUz

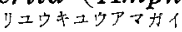

Cyclophoridae

29. Cyclophorus turgidus (PHEIFFER)

Littorinidae

30. Tectarius (Nodilittorina) granularis (GRAY)
Takarazima Nakanosima

443

446

447

448

449,450

mem.

mem.

451

452

453

$454-458$

mem. *

459, 460

461

462

463

316

317

318

319

320

321

322

323

324

325

326

327-330

331

464 
31. Tectarius (Nodilittorina) pictus (PHILIPPI)

Takarazima

32. Tectarius (Nodilittorina) vilis (MENKE)

33. Littorinopsis scabra (LINNÉ)

34. Littorinopsis undulata (GRAY)

35. Littorinopsis pintado (WOOD)

36. Littorinopsis obesa (SowERBY)

335

342

341
Nakanosima

333

345

334

346

347

38. Rissoina subfirmata BOETTGER

フトスジジウシター

Assimineidae

39. Paludinella stricta Gould

348

40. Angustassiminea castanea satumana HABE

Vermiculariidae

41. Vermetus gordialis MöRCH

42. Spiroglyphus sp.

43. Lemintina sp.

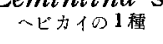

44. Bivonia dragonella KURODA MS.

Thiaridae

45. Semisulcospira libertina (GouLd)

Planaxidae

46. Planaxis (Angiola) virgatus SмIтн

Cerithiidae

47. Bittium (Plesiotrochus) oosimense (WATSON)

48. Cerithium (Ochetoclava) sinense (GMELIN)

360

49. Contumax echinatus (LAMARCK)

361

50. Semivertagus nesioticus (PILSBRy \& VANATtA)

362

51. Semivertagus zebra (KIENER)

52. Semivertagus stigmosus (GovLd)

53. Conocerithium atromarginatum (DESHAYES) 
Triphoridae

54. Triphora lamberti (HERVIER)

55. Triphora $\mathrm{sp.}$

Epitoniidae

56. Gyroscala perplexa (PEASE)

57. Epitonium (Foliaceiscala) dubia (SOWERBY)

Janthinidae

58. Janthina janthina (LINNÉ)

59. Janthina balteata REEVE

60. Janthina (Violetta) globosa BLAINville

61. Janthina (Iodina) umbilicata d'ORBIGNY

62. Recluzia montrouzieri BRAZIER

Naticidae

63. Polinices (Gloussaulax) didyma (RöDING)

64. Natica (Naticarius) concinna DUNker

65. Natica (Notocochlis) picta RéCLUZ

66. ?Natica (Notocochlis) sagittata Menke

67. Natica (Tanea) rufilabris REEVE

Merriidae

68. Merria ligata (RÉCLUZ)

69. Merria gueriniana (RÉCLUZ) イカカケンロホズミカイ

Amaltheidae

70. Amalthea (Antisabia) foliacea (QUOY \& GAIMARD)

71. Pilosabia pirosa (Deshayes)

$$
x \geq x \operatorname{pi}_{1}
$$

Calyptraeidae

72. Cheilea equestris (LINNÉ)

Strombidae

73. Strombus (Conomurex) luhuanus LiNNê 74. Strombus (Canarium) urceus LINNÉ
468

Takarazima Nakanosima

367

368

228

229

mem.

230

231

232 mem.

233 mem.

234

mem.

475

476

478

467

466

(1)

71

mem.

473

474 
75. Strombus (Aliger) latissimus LıNNÉ

Takarazima mem.

76. Lambis $\underset{\sharp}{\operatorname{lambis}}$ (LINNÉ)

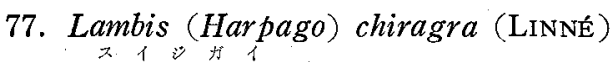

Eratoidae

78. Erato (Eratoena) sulcifera nana (Sowerby)

79. Trivirostra edgari (SHAw)

$$
\text { ヘダカムギカ十 } 1
$$

Amphiperatidae

80. Pedicularia pacifica PEASE

81. Calpurnus (Procalpurnus) lacteus (LAMARCK)

82. Amphiperas ovum (LINNÉ)

Cypraeidae

83. Pustularia cicercula (LINNÉ)

84. Pustularia globulus (LiNNÉ) メンタチサリ多フ

85. Naria (Paulonaria) beckii (GASKOIN)

86. Staphylaea staphylaea (LINNÉ)

87. Staphylaea (Nuclearia) uncleus (LINNÉ)

88. Erosaria (Ravitrona) caputserpentis reticulum (GMElin) ハナマル亡*

89. Erosaria (Erosaria) helvola (LinNé)

90. Erosaria (Erosaria) poraria scarabaeus (BORY)

91. Erosaria (Erosaria) erosa phagedaina (Melvill) $\exists$ モ

92. Monetaria (Ornamentaria) annulus harmandiana (ROCHEBRUNE) 八+ビラタカ

93. Monetaria (Monetaria) moneta rhomboides SCHILDER \& SCHILDER † 1 口名

94. Erronea (Evenaria) artuffeli (JoussEAUME)

95. Erronea (Evenaria) fimbriata (GMELIN)

96. Erronea (Derstolida) ursellus (GMELIN)

97. Erronea (Derstolida) kieneri deprieteri (ScHILDER)

98. Erronea (Talostolida) teres (GMELIN)

99. Erronea (Ovatipsa) chinensis (GMELIN)

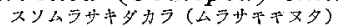

mem.

mem. mem.

mem.

445

208

mem. 
100. Erronea (Cribraria) cribraria orientalis

$\begin{array}{cc}\begin{array}{c}\text { Takarazima } \\ 187\end{array} & \text { Nakanosima } \\ 194 & 195 \\ 196 & 197 \\ 198,199 & 200 \\ 201 & \text { mem. }\end{array}$

101. Luria (Basilitrona) isabella rumphii

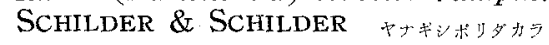

102. Mauritia (Arabica) scurra indica (GMELIN) 202,203

105. Cypraea (Ponda) carneola LINNÉ 205 106. Cypraea (Lyncina) vanelli LINNÉ

Cassididae

107. Cassis cornuta (LiNNé) mem.

Cymatiidae

108. Cymatium (Gelagna) clandestinum (LAMARCK) 372

109. Cymatium (Septa) aquatile (REEve) 369

110. Cymatium (Septa) rubecula (LINNÉ) 370,371

111. Cymatium sp.

112. Charonia tritonis (LINNE) mem.

113. Colubraria clathrata (SowERBY)

Bursidae

114. Bursa (Dulcerana) corrugata (PERRY) 375

115. Bursa (Dulcerana) jabick (RöDING) 376

116. Bursa (Bursa) bufonia (GMELIN)

Tonnidae

117. ?Tonna luteostoma (KÜSTER) mem.

118. Tonna perdix (LINNE)

Muricidae

119. Chicoreus rubicundus (PERRY)

120. Drupa (Cronia) margariticola (BRODERIP)

121. Drupa (Maculotriton) digitalis (REEVE)

122. Drupa (Maculotriton) serrialis longa (PILSBRY \& VAnatTA) コマフヌカ术ク 
123. Drupa (Morula) aspera (LAMARCK)

Takarazima

Nakanosima

124. Drupa (Morula) granulata (Duclos)

243

244

245-248

125. Drupa (Morula) anaxares (KIENER)

249,250

251

126. Drupa (Morula) borealis (PILSBRY)

252

127. Drupa sp.

253

128. Drupa (Morulina) pothuoui (SOULEyeT)

254

129. Drupa (Morulina) sp.

255

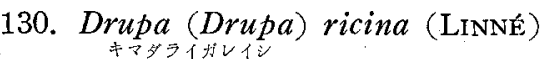

256

131. Drupa $\underset{i}{(D r u p a)}$ albolabris (BLAINville)

258

132. Drupa (Drupa) morum RöDING

259-261

133. Drupa (Drupa) spathulifera (Blainville)

263,264

134. Drupa (Drupa) rubuscaesius (RöDING)

266

267

135. Drupella cornus (RöDING)

268

136. Purpura persica (LINNÉ)

137. Purpura rudolphi (LAMARCK)

273, 274

138. Purpura armigera (LINK)

139. Purpura tuberosa (RöDING)

275,276

140. Purpura kieneri (Deshayes)

278

279

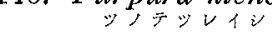

280,281

282

141. Purpura distinguenda (DUNKer \& ZELEBOR)

Rapidae

142. Coralliophila violacea (KIENER)

143. Coralliophila squamulosa (REEve)

287

144. Coralliobia (Quoyula) monodonta (BLAINville)

145. Leptoconchus striatus RÜPPELL

146. Leptoconchus rostratus (A. ADAMs)

Pyrenidae

147. Pyrene punctata (BkUguiÈre)

148. Pyrene (?) testudinaria (LINK)

149. Anachis (Zafra) sinensis (SOWERBY) 
150. Anachis (Anachis) liocyma (PILSBRY)

Takarazima Nakanosima 293

151. Columbella (Euplica) borealis PILSBRY 294 259

152. Columbella (Euplica) varians SOWERBY 296

Buccinidae

153. Engina lineata (REEVE) 301

154. Engina melanozona ToMLIN 302

155. Engina mendicaria (LINNÉ)

303 304

156. Pisania (Japeuthria) cingulata (REEve) 297

157. Pisania (Ecmanis) tritonoides (REEVE) 298

158. Cantharus (Pollia) rubiginosus (REEVE)

159. Cantharus (Pollia) undosus (LINNE)

Nassariidae

160. Phrontis crassus (PHILIPPI)

305

161. Nassarius (Alectrion) papillosus (LINNÉ) 306

162. Nassarius (Zeuxis) mucronatus (A, ADAMS)

Fasciolariidae

163. Latirus polygonus (GMELIN)

164. Latirus craticulatus (LINNÉ)

165. Latirus (Latirulus) turritus (GMELIN)

312

166. Latirus (Mazzalina) smaragdula (LINNé)

167. Peristernia nassatula (LAMARCK)

Olividae

168. Oliva emicator (MEUSCHEN)

Mitridae

169. Pusia pardalis consanguinea (REEVE)

170. Pusia cancellarioides (AnTON)

171. Mitra (Chrysame) chrysalis REEvE

172. Mitra (Mitra) stictica (Link) 
174. Mitra (Strigatella) paupercula (LINNÉ)

Takarazima

Nakanosima

175. Mitra (Strigatella) zebra (LAMARCK)

176. Mitra (Strigatella) virgata REEvE

221

220

177. Mitra (Strigatella) decurtata REEvE

178. Mitra (Dibaphus) edentula (REEve)

179. Pterygia dactylus (LINNÉ)

Vasidae

180. Vasum turbinellum (LINNÉ)

226

181. Vasum ceramicum (LINNÉ)

Turridae

182. Clavus (Tylotia) exilis (PEASE)

183. Kermia chichijimana PILSBRY var.

184. Philbertia sp.

Conidae

185. Conus (Chelyconus) catus BRUGUIÈRE

186. Conus (Stephanoconus) lividus BRUGUIÈRE

386,387

388

187. Couns (Lithoconus) flavidus LAMARCK

389

390

188. Conus (Rhizoconus) rattus BRUGUIÈRE

189. Conus (Pinoconus) cinereus BRUGUIERE

406,407

190. Conus (Virroconus) ebraeus LINNÉ

391,392

408, 409

191. Conus (Virroconus) chaldaeus (RöDING)

394

192. Conus (Virroconus) musicus BRUGUIERE

397 395,396

193. Conus (Virroconus) fulgetrum SowERBY 399,400 398

194. Conus (Virroconus) coronatus GMELIN

402
404
403
405

196. Conus (Gastridium) obscurus REEvE 410

197. Conus (Gastridium) tulipa LINNÉ

198. Conus (Darioconus) retifer MENKE 
Pyramidellidae

199. Otopleura glans (REEVE) 200. Miralda gemma (A. ADAMs)

Atyidae

201. Atys (Aliculastrum) cylindrica (Helbling)

202. Haloa binotata (PILSBRY) ニクイロフドウガ

Cavolinidae

203. Diacria trispinosa (BIAINVILLE)

204. Cavolinia uncinata (RANG)

205. Cavolinia globulosa (RANG)

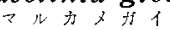

Ellobiidae

206. Laemodonta hirsuta (GARRETT)

207. Melampus caffer (KüSTER)

Siphonariidae

208. Siphonaria laciniosa (LinNé)

209. Siphonaria rucuana PILSBRY 二ヒ匕トカラマッカ1

210. Siphonaria atra QuOY \& GAIMARD

211. Siphonaria subatra PILSBRY

Lymnaeidae

212. Lymnaea sp.

Onchidiidae

213. Onchidium verruculatum CUVIER

427,428

Clausiliidae

214. Zaptyx (Metazaptyx) tokarana (PILSBRY)

Bradybaenidae

215. Bradybaena phaeogramma (ANCEY)

216. Bradybaena (Acusta) despecta (SOWERBY)

217. Satsuma oshimae (PILSBRY)

218. Euhadra pachya (PILSBRY)
421

mem.

430

236

419

424

425

mem.

429

434 


\section{PELECYPODA}

Arcidae

219. Arca avellana LAMARCK

220. Barbatia bicororata (DILLWYN)

221. Barbatia lima (REEVE)

222. Acar plicata (DILlWYN)

Mytilidae

223. Volsella plumescens (DUNKER)

224. Brachidontes (Hormomya) mutabilis (GovLD)

225. Septifer bilocularis (LINNE)

226. Septifer excisus (WIEGMANN)

227. Lithophaga (Doliolabis) lithura PILSBRY

$$
\text { T. } \rightarrow 11 \mathrm{i} \rightarrow=
$$

Isognomonidae

228. Isognomon marsupialis (RÖDING)

229. Isognomon acutirostris (DUNKER)

Pteriidae

230. Pinctada panasesae (JAmESON)

ミ・リア本少办1

Pinnidae

231. Pinna (Quantulopinna) muricata LINNÉ

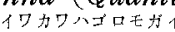

Pectinidae

232. Plicatula horrida Dunker

233. Chlamys (Gloripallium) pallium (LINNÉ)

234. Chlamys (Chlamys) schmeltzii (KOBELT)

235. Spondylus squamosus SchreIBERS

236. Spondylus sanguineus DUNKER

Ostreidae

237. Gryphaea (Saxostrea) mordax Gould

Trapeziidae

238. Trapezium oblongum (LINNÉ)
119

120

Takarazima Nakanosima

92, 93

94

95

96

97

98

99

100

101

102

103

104,105

106

107-110, 113 111, 112, 114

115

116, 166

117

118

123-129

130, 131 
Codakiidae

239. Codakia paytenorum (IREDALE)

240. Codakia delicatula (PILSBRY)

Erycinidae

241. Kellia cycladiformis (DESHAYES)

Chamidae

242. Chama iostoma CoNRAD

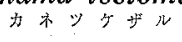

243. Chama brassica REEve (var.)

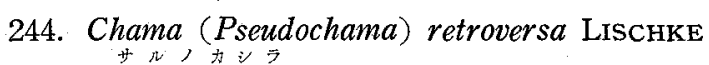

Tridacnidae

245. Tridacna (Vulgodacna) maxima (RöDING)

246. Tridacna (Chametrachea) crocea (LAMARCK)

Veneridae

247. Gafrarium dispar (DILlwyN)

248. Gafrarium pectinatum (LINNÉ)

249. Meretrix meretrix lusoria (RöDING)

250. Venus (Periglypta) reticulata LINNÉ

Asaphidae 251. Asaphis dichotoma (ANTON)

Semelidae

252. Semele carnicolor (HANLEY)

Tellinidae

253. Cyclotellina (Scutarcopagia) scobinata (LINNÉ)

254. Fabulina (Jactellina) obliquestriata (SowERBY)

\section{CEPHALOPODA}

Nautilidae

255. Nautilus pompilius LINNÉ

Argonautidae

256. Argonauta hians SOlANDER
Takarazima Nakanosima

159

160

161

162

164

132-134

135,136

137

138

163

141

142

143

144

145

146,147

148

149-151

152

153

157

$154,155 \quad 156$

165 


\section{General Remarks on the Molluscan Fauna}

From the last author's observations on the islands and from an examination of the present material, some of the following features seem to be accepted safely as hints of the characteristics of the molluscan fauna of these islands.

\section{Common shells in Takarazima and Nakanosima.}

Pelecypoda: Asaphis dichotoma (AnTon) is the commonest species in both islands, next is Venus (Periglypta) reticulata LINNE. Cyclotellina (Scutarcopagia) scobinata (L.) is common in Takarazima, but rather rare in Nakanosima.

Neritidae: Nerita (undata) striata Burrow, Nerita (Ritena) plicata L. and Nerita (Theliostyla) albicilla $\mathrm{L}$. are met with frequently in both Takarazima and Nakanosima. Nerita (Ritena) helicinoides laevilabris PILSBRY was common in Takarazima, but not found at all in Nakanosima where Nerita (Amphinerita) insculpta RÉCLUZ was found rather commonly. Nerita (Amphinerita) polita L. is more abundant in Nakanosima than in Takarazima. Nerita (Ritena) costata GMELIN is very rare in both islands.

Littorinidae: The littorinid fauna in both islands mostly consist of Tectarius (Nodilittorina) vilis (MENKE). In Nakanosima, a considerable number of Tectarius (Nodilittorina) granularis (GRAY) and Littorinopsis undulata (GRAY) were found in the littorinid zone, while in Takarazima the last author found only 3 shells of the former and 2 of the latter, which are less than $7 \mathrm{~mm}$ in height against $13 \mathrm{~mm}$ in individuals from Nakanosima. Littorinopsis obesa (SOWERBY) was found sparsely in Takarazima. Tectarius (Nodilittorina) pictus (PHILIPPI), Littorinopsis pintado (Wood) and Littorinopsis scabra (L) were all very rare. Generally speaking the littorinid fauna is very simple in Takarazima, this is probably due to poor flow of the fresh water and the regular outline of the island.

Cypraeidae: Mauritia (Mauritia) mauritiana calxequina (Melvill \& StAnden) and $M$. (Arabica) arabica asiatica SchILDER \& SCHILDER are common in both islands. Pustularia was met with frequently only in Takarazima.

Muricidae : Drupa (Drupa) morum RöDING and Drupa (Drupa) ricina (L.) are common in both Takarazima and Nakanosima, slightly commoner in the former locality than in the latter. Drupa (Cronia) margariticola (BRODERIP), Drupa (Morulina) sp. (No.129) and Drupa (Drupa) albolabris (BlAInvilie) were found rather commonly in Takarazima, but not found at all in Nakanosima. Purpura kieneri (Deshayes) was found in both islands, while shells of Purpura persica (L.) and $P$. rudolphi (LAM.) were found only in Nakanosima. P. persica and P. rudolphi are generally used for food by the inhabitants in Nakanosima and this is the reason 
why remains of these snails were found abundantly on that island.

Buccinidae : Engina mendicaria (L.) is common on the reef in both islands.

Mitridae : Mitra (Strigatella) virgata REEvE and Mitra (Strigatella) decurtata REEVE are common in both islands. A considerable number of $M$. (St.) litterata LAM. and $M$. (St) zebra LAM. were found also in Takarazima.

Conidae: Conus (Virroconus) ebraeus L. and G. (V.) chaldaeus (RöDING) are the commonest conids in both islands. $C$. (Stephanoconus) lividus BRUGUIĖE, $C$. (Lithoconus) flavidus LAM., C. (V.) fulgetrum Sow., C. (Pinoconus) cinereus BRUGUIÈRE and C. (Rhizoconus) rattus BRUGUIÈRE, all yellowish brown in colour when alive, were found rather frequently.

Siphonariidae: The siphonariid fauna differs distinctly between Takarazima and Nakanosima. In the former, Siphonaria rucuana PILsBRy and S. laciniosa (L.) were found commonly, especially $S$. rucuana which was found only in this island. In the latter, S. subatra PILSBRy was found commonly; S. atra Q. \& G. was found solely in this island, though few in number.

Brackish area: Melampus caffer (Küster) is common in both islands. Paludinella stricta GoulD* was common in Nakanosima, while in Takarazima Angustassiminea castanea satumana $\mathrm{HABE}$ was found frequently.

Land shells : Empty shells of Bradybaena (Acusta) despecta (SOWERBY) scattered very abundantly in "Sabaku" of Takarazima were one of the most impressive sights in this island.

\section{Species found under stones.}

Isognomon perna (L.) and Planaxis (Angiola) virgatus SMITH occur commonly in both islands. The molluscs found under stones are much richer in Takarazima than in Nakanosima; namely Pinctada panasesae (JAmeson), Chama brassica Reeve (var.), Anachis (Zafra) sinensis (Sow.), Emarginula variegata A. AdAms, Collonista granulosa (PEASE), Triphora sp., Kermia chichijimana Pilsbry var. and Bittium (Plesiotrochus) oosimense (WATSON) were found in Takarazima in a considerable number. The last one of these species was found also in Nakanosima, but very few in number.

\section{Some characteristics of the molluscan fauna in both islands.}

Rich fauna in Takarazima: 204 species occurred in Takarazima and 141 species

* Angustassiminea castanea satumana HABE read in the 24 th line, p. 135, Vol. III, No. 2 of this journal must be corrected as Paludinella stricta Gould. 
in Nakanosima. Small or delicate shells, for instance Atyids or Pteropods are found much more abundantly and perfectly in Takarazima than in Nakanosima. This is probably due to the topographic difference between the coasts of the islands. The beach of Nakanosima seems to be too rough to preserve those shells perfectly. Nevertheless, the molluscan fauna of Nakanosima has some representatives which are very rare or not included in the collection from Takarazima, namely Septifer excisus (WiegmanN), Spondylus spp., Tridacna (Vulgodacna) maxima (Röding), Cellana spp., Vermiculariids and Rapids.

Differences of size and colour in some species: Isognomon acutirostris (DUNKER) reaches $21 \mathrm{~mm}$ in length in Takarazima, while most of shells from Nakanosima are less than $9 \mathrm{~mm}$ in length, although some stranded empty shells reach $24 \mathrm{~mm}$. Gry. phaea (Saxostrea) mordax Gould seems to grow better in Takarazima than in Nakanosima; it reaches $40 \mathrm{~mm} \times 65 \mathrm{~mm} \sim 45 \mathrm{~mm} \times 70 \mathrm{~mm}$ in size of the shell in the former, while the largest shells in the latter location are $20 \mathrm{~mm} \times 45 \mathrm{~mm} \sim 25 \mathrm{~mm}$ $\times 35 \mathrm{~mm}$. Some shells attached to the stones near the mouth of the brook on the western coast of Nakanosima are very irregular in shape and assume a generally peculiar appearance which may easily lead to misidentification. Purpura kieneri (Deshayes), Nerita (undata) striata Burrow and Nerita (Ritena) plicata L. are all smaller in Nakanosima than in Takarazima; respectively $25 \mathrm{~mm}$ in height in Nakanosima and $35 \mathrm{~mm}$ in Takarazima, $22 \mathrm{~mm}$ in diameter in Nakanosima and $27 \mathrm{~mm}$ in Takarazima, and $14 \mathrm{~mm}$ in diameter in Nakanosima and $22 \mathrm{~mm}$ in Takarazima. Among the living animals examined, Nerita (Theliostyla) albicilla L. seems to be coloured darker in Nakanosima than in Takarazima. Nerita (Amphinerita) polita L. shows the same tendency and at the same time shows a richer variety of colouration and pattern in Nakanosima.

Occurrence of tropical shells in Takarazima: Cassis cornuta (L.), Strombus (Aliger) latissimus L. and Lambis lambis (L.) were observed only in Takarazima, although they were all stranded empty shells. The shell of Lambis (Harpago) chiragra (L.) was found in both islands, but that observed in Nakanosima was a young one. Turbo (Olearia) marmoratus L., the most important gastropod in these islands both as the source of the material for the artistic shellwork and as an important source of food, is also much more abundant in Takarazima than in Nakanosima. 